flask positioned to receive the effluent.

Since the basic component glassware is readily available and inexpensive, repair and replacement costs and time lost in experimentation have been minimized. These facts should permit anyone with a moderate budget to use a similar apparatus.

As in the use of all semi-continuous or continuous culture devices, caution must be exercised in order to avoid contamination. However, if the principles governing sterile technique are observed, contamination does not pose a problem, because the entire system is essentially closed except during the short (one- to two-minute) sampling period.

References

Málek, I., Beran, K., Fencl, Z., Munk, V., Řixica, J., and Smrčková, H., eds. (1969). Continuous Cultivation of Microorganisms. Academic Press, New York.

Málek, I., and Fencl, Z., eds. (1966). Theoretical and Methodological Basis of Continuous Culture of Microorganisms. Academic Press, New York.

Monod, J. (1950). La technique de culture continue theorie et applications. Ann. Inst. Pasteur, 79, 390-410.

Novick, A., and Szilard, L. (1950). Experiments with the chemostat on spontaneous mutations of bacteria. Proc. nat. Acad. Sci. (Wash.), 36, 708-719.

\section{An adjustable, semi-automatic dispenser for use with dry absorbents in protein-binding techniques} K. H. OUTCH, P. M. DENNIS, AND J. CULROSS From the
Department of Chemical Pathology, Prince Henry's
Hospital, Melbourne, Australia

The assay of steroid hormone levels in plasma often requires the addition of precise amounts of a dry absorbent, such as florisil, to separate the free from the protein-bound components. To achieve this various dispensers have been constructed and described, ranging in complexity from the simple calibrated spoon described by Murphy (1967) to the more elaborate semi-automatic dispenser described by Castro, Klein, and Cryderman (1970). Modification of the dispenser described by Bayard, Beitins, Kowarski, and Migeon (1970) has resulted in a semiautomatic dispenser which is robust, has a high degree of precision, is of simple construction, and has the further advantage of being adjustable to deliver various amounts of the dried material.

\section{Construction}

The dispenser was made from a $250 \mathrm{ml}$ separating flask fitted with a teflon stopcock. The stopcock was removed and its existing channel widened to $6 \mathrm{~mm}$. At one end the channel was widened to a diameter of $10 \mathrm{~mm}$ to form a recess which was $2.5 \mathrm{~mm}$ deep. Using $10 \mathrm{~mm}$ diameter teflon rod a plug was made as shown in Figure 1. The diameter of the shaft was $6 \mathrm{~mm}$, the head $10 \mathrm{~mm}$ in diameter and $3 \mathrm{~mm}$ thick. The plug was inserted into the stopcock and pushed home. The head of the plug was then shaped to match the contour of the stopcock. A punch mark was placed on the stopcock and the plug to allow correct alignment of the plug for subsequent insertions.

Using a scalpel blade the shaft of the plug can be reduced in length until the desired amount of absorbent is delivered (a shaft length of $7 \mathrm{~mm}$ delivered about $40 \mathrm{mg}$ of florisil). With this technique plugs have been made which, when inserted into the stopcock, will deliver approximately $40 \mathrm{mg}, 60 \mathrm{mg}$, and $90 \mathrm{mg}$ of florisil. One of the side arms of the

Received for publication 25 May 1972. 


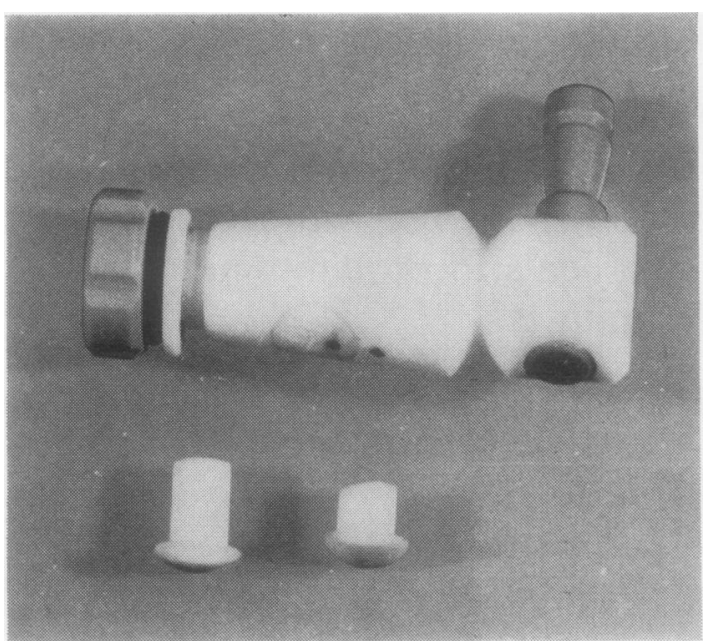

Fig. 1 Modified stopcock with plugs.

stopcock was removed, as shown in Fig. 1 so that the one remaining could be used to indicate the filling and emptying positions of the dispenser, as well as to turn the stopcock in the barrel. ensure complete delivery. By turning the stopcock with the right hand visual examination of the $\underline{0}$ absorbent can be made before delivery to ensure that $\Rightarrow$ the dispensing well is completely filled.

\section{Results}

To measure the precision of our dispenser 25 weighings were made at each of the three levels dispensed. The plugs were removed and interchanged in a random fashion and a further 10 weighings were $\overrightarrow{0}$ made at each level as a check on the reproducibility of the dispenser. This procedure was carried out $\vec{\omega}$ twice and the results obtained are shown in Table I.

\section{Comments}

The performance of the solid phase dispenser described has compared very favourably with the $N$ findings of Murphy (1967) who obtained a precision $\vec{\circ}$ of $39.3 \pm 1.3 \mathrm{mg}$ (range 37.0 to 41.4 ) for 10 observa- 8 tions using a calibrated spoon. Castro, Klein, and Cryderman (1970), using a semi-automatic dispenser for 25 deliveries, obtained a range of 74.1 to $75.9 \mathrm{mg}$ $(75.0 \pm 0.09 \mathrm{mg} \mathrm{SD})$. With this dispenser it is possible to add absorbent quickly and precisely to $\exists$ large numbers of tubes, overcoming the problem of $\Phi$ the loss of precision which tends to occur with a repetitive measuring procedure.

\begin{tabular}{|c|c|c|c|c|c|c|c|c|c|}
\hline & \multicolumn{3}{|c|}{ '70 mig' Plug } & \multicolumn{3}{|c|}{ ‘60 mg` Plug } & \multicolumn{3}{|c|}{ '90 mg' Plug } \\
\hline & 1 & 2 & 3 & $l$ & 2 & 3 & $I$ & 2 & 3 \\
\hline$X(m g)$ & $44 \cdot 2$ & $44 \cdot 5$ & $44 \cdot 6$ & $66 \cdot 0$ & $63 \cdot 8$ & $66 \cdot 3$ & $93 \cdot 7$ & $91 \cdot 3$ & $93 \cdot 1$ \\
\hline $\mathrm{SD}$ (mg) & $1 \cdot 1$ & 0.9 & 0.6 & $1 \cdot 1$ & 0.8 & $1 \cdot 1$ & $1 \cdot 2$ & 0.7 & 0.8 \\
\hline CV $(\%)$ & $2 \cdot 6$ & 1.9 & $1 \cdot 4$ & $1 \cdot 7$ & $1 \cdot 3$ & $1 \cdot 7$ & $1 \cdot 3$ & 0.8 & 0.9 \\
\hline Nuriber of observations & 25 & 10 & 10 & 25 & 10 & 10 & 25 & 10 & 10 \\
\hline
\end{tabular}

Table I Precision of dispenser delivery

\section{Operation}

To fill the dispenser the stopcock is turned until the side arm is in the upper position. By turning the stopcock continually through $180^{\circ}$ the dispenser will automatically fill and dispense the required amount of absorbent material. When delivering absorbent to a tube the stopcock is tapped gently to

\section{References}

Bayard, F., Beitins, I. Z., Kowarski, A., and Migeon, C. J. (1970) Measurement of plasma aldosterone by radioimmunoassay J. clin. Endocr., 31, 1-6.

Castro, A., Klein, W. D., and Cryderman, W. G. (1970). Semiautomatic device for dispensing absorbent materials in proteinbound steroid assay. Steroids, 15, 561-562.

Murphy, B. E. (1967). Some studies of the protein binding of steroids and their application to the routine micro and ultra-micro measurement of various steroids in body fluids by competitive protein binding radioassay. J. clin. Endocr., 27, 973-990. 